\title{
A NEW RECORD EXPANDING THE RANGE OF AMPHIDROMUS SINENSIS (BENSON, 1851) (GASTROPODA: CAMAENIDAE)
}

\author{
BasudeV Tripathy, SheikH Sajan*, Priyadarsi Girija SANKar Sethy, Paromit ChatTerJeE, \\ KAILASH CHANDRA
}

\begin{abstract}
Zoological Survey of India, Prani Vigyan Bhawan, M Block, New Alipore, 700053 Kolkata, India (e-mails: tripathyb@gmail.com; sksajan.sajan@gmail.com; priyadassi@gmail.com; paromitchatterjee@gmail.com; kailash616@gmail.com)

*corresponding author
\end{abstract}

ABSTRACT: We present a new record of a little known tree snail Amphidromus sinensis (Benson) from the Similipal Biosphere Reserve in Odisha. It is the first record from the peninsular region of India and is remote from the previously known range. The distribution suggests either dispersal of the species through the Malayan region to northeast India, through Assam hills to Chotta-Nagpur plateau, to further Eastern Ghats, or a spread which took place during the Pleistocene, with the isolated population remaining in the region.

KEY WORDS: land snails, Camaeninae, range-extension, biogeography, dispersal, India

The genus Amphidromus Albers, 1850 includes tree-dwelling snails. Its distribution range extends from Assam in India to Indochina and to Sundaland, south to the Philippines, Wallacea, with one species in Australia (PILSBRY 1900, LAIDLAW \& SOLEM 1961, SOLEM 1983, MitrA et al. 2004, SUTCHARIT \& PANHA 2006, RAMAKRISHNA et al. 2010, SUTCHARIT et al. 2015, INKHAVILAY et al. 2017). A. sinensis (Benson, 1851) was reported e.g. from the Khasi Hills, Assam, India; Chittagong, Bangladesh; Pegu and Shwegyeen, Myanmar, with one variety occurring in Laos (GUDE 1914).

The Amphidromus specimen found during the 2005 field survey of the Similipal Biosphere Reserve, Odisha (SETHY et al. 2007) and the specimens from the National Zoological Collection at Zoological Survey of India (ZSI) provided the basis for this note. The specimens were identified using keys and guides by GUDE (1914), MitrA et al. (2004), BANK (2017) and BOUCHET et al. (2017). The forest type deter- mination was based on the WWF-Global Ecoregion dataset (OLSON et al. 2001).

A. sinensis (Benson, 1851) (Fig. 1) is now recorded from the Similipal Biosphere Reserve in Odisha $\left(21^{\circ} 38^{\prime} 24.8^{\prime \prime} \mathrm{N}, 86^{\circ} 17^{\prime} 59.4^{\prime \prime} \mathrm{E}, 870 \mathrm{~m}\right.$ a.s.l.); this is the first record from the peninsular region of India (Fig. 2). Although basically a rainforest species, in the new locality it was found (one specimen) in a dry deciduous forest. The new record is remote from the previously known range. All the records of $A$. sinensis come from tropical and subtropical moist broadleaf forests (Fig. 2). An earlier study on the genus Amphidromus indicates temperature as an important factor; temperature changes may affect the future distribution of the genus (KLORVUTTIMONTARA et al. 2017). Our observation suggests that $A$. sinensis is very sensitive to climate. Land snails disperse over long distance only through passive dispersal. Besides, species of Amphidromus are known to disperse through tree canopies and linked branches (KLORVUTTIMONTARA 


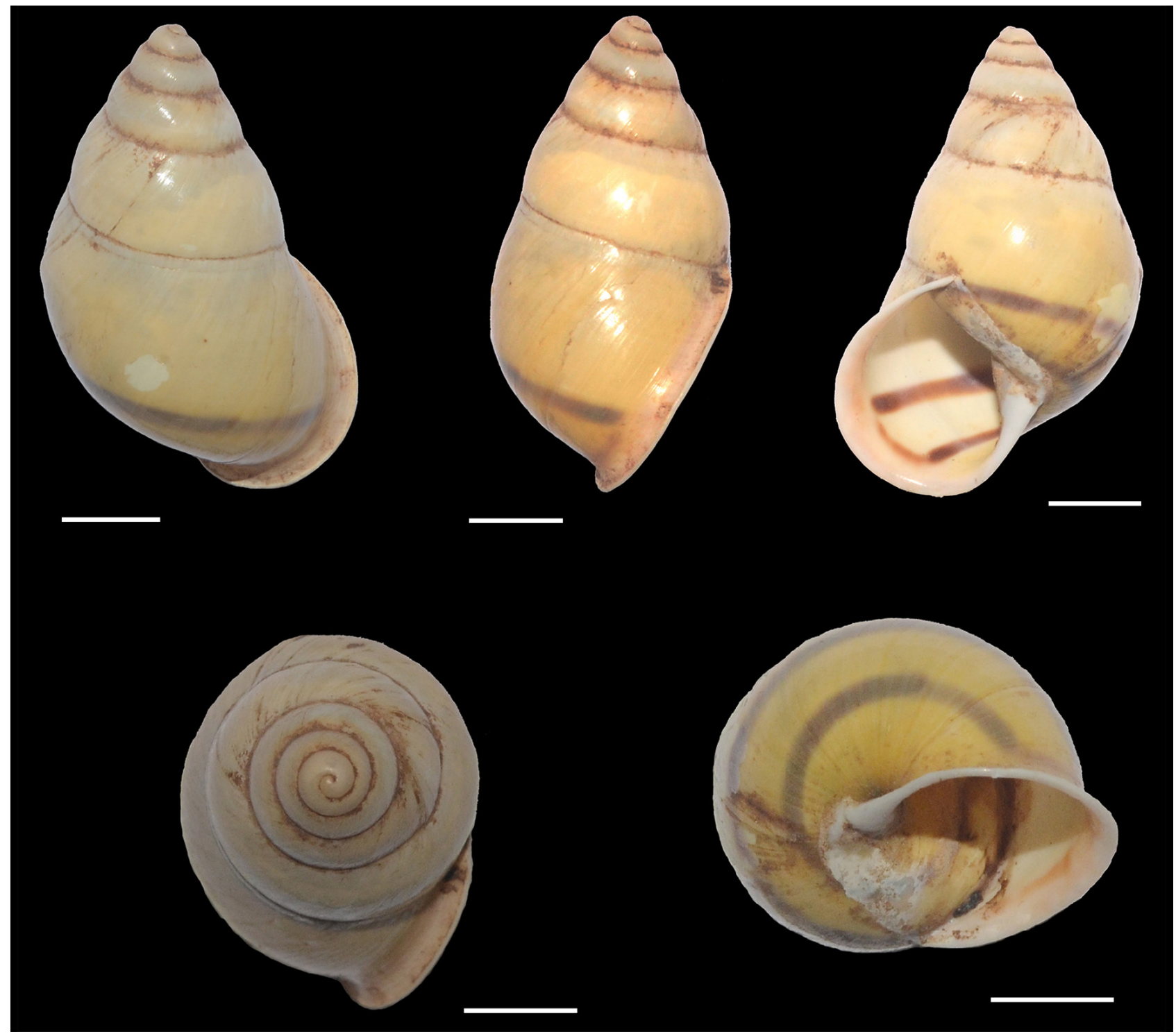

Fig. 1. Shell of Amphidromus sinensis from the Similipal Biosphere Reserve of Odisha, India (scale bar $5 \mathrm{~mm}$ )

et al. 2017). Apart from these dispersal methods, climate specificity may also be a reason for the occurrence of the genus in some localities (SUTCHARIT \& PANHA 2006), in this case the Similipal Biosphere Reserve in Odisha.

The distribution of the wet zone fauna (mammals, birds, fishes, reptiles, amphibians and annelids) from the Malayan region to the Indian Peninsula is discontinuous (ABDULALI 1949, HORA 1949, ROONWAL \& NATH 1949, MANI 1974, KARANTH 2003). The occurrence of $A$. sinensis in the Indian Peninsula may be associated with its preferences to climate which are more or less similar in all the sites. It can be conjectured that either its dispersal route was through the Malayan region to northeast India, through the Assam Hills to the Chotta-Nagpur plateau, to further Eastern Ghats, supporting Satpura Hypothesis (HORA 1949), or it took place during the Pleistocene, with the isolated population now still surviving in the region. Further studies are necessary to specify the dispersal routes of $A$. sinensis.

\section{ACKNOWLEDGEMENTS}

We are grateful to the Director, Zoological Survey of India, Kolkata for providing the necessary facilities and encouragement. Our thanks go to The Principal Chief Conservator of Forests (Wildlife), Government of Odisha and Field Director, Similipal Tiger Reserve, for providing the survey permit and logistic support. The research fellowship supported by National Mission on Himalayan Study, Grant no. NMHS-LG-2016/0011/8509-8, dated 31.03.2016 funded by MoEF\&CC, Government of India to the SS and PC. We thank the editors, ANDRZEJ LESICKI and JAROSŁAW BOGUCKI, and anonymous reviewer for their valuable suggestions towards improving the manuscript. 


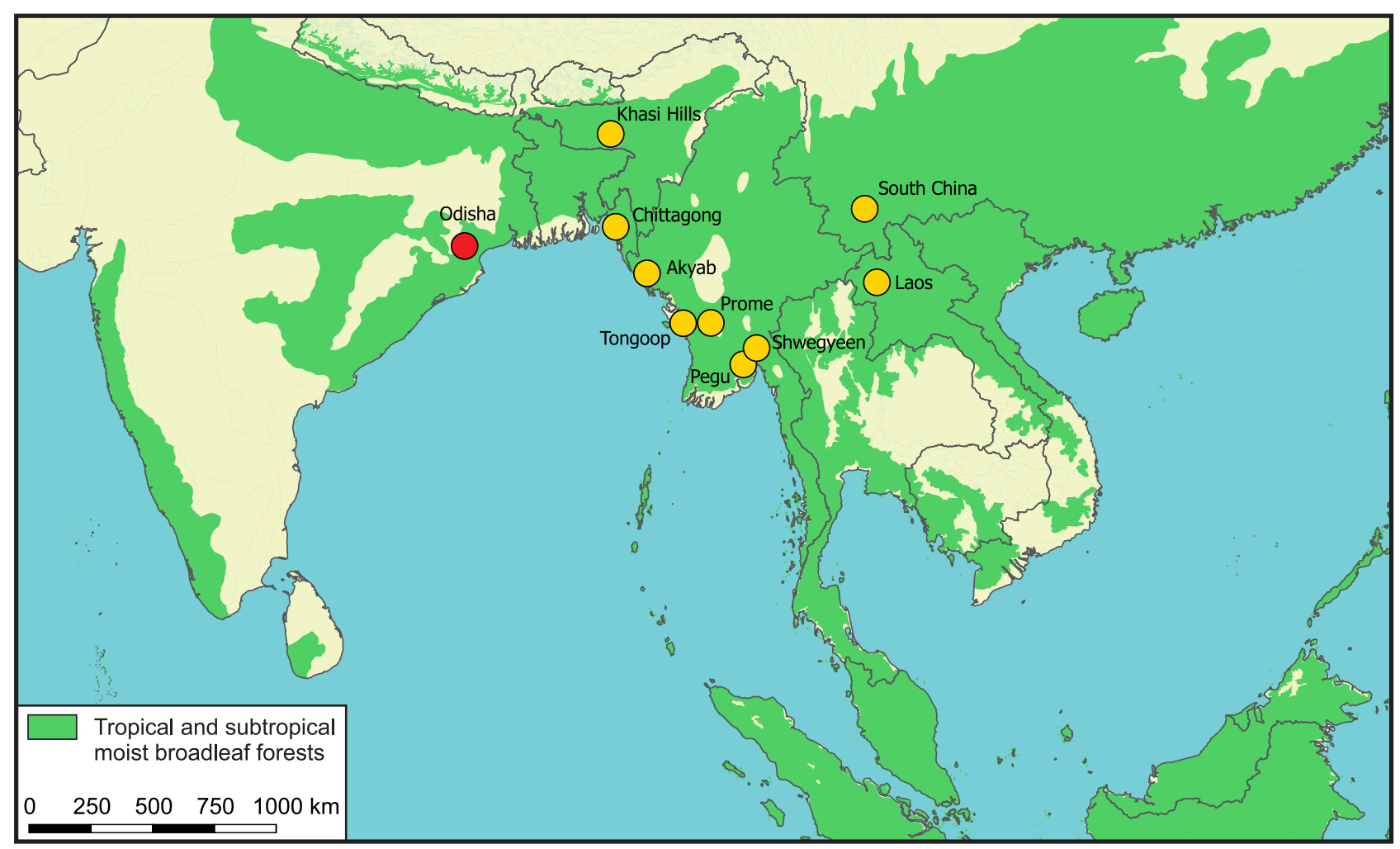

Fig. 2. Present (red dot) and past according to GUDE (1914) (yellow dots) localities of Amphidromus sinensis (Benson, 1851) in south and south-east Asia

\section{REFERENCES}

ABDUlali H. 1949. Some peculiarities of avifaunal distribution in peninsular India. Proceedings of the National Institute of Sciences of India 15: 387-393.

BANK R. 2017. MolluscaBase: classification of the recent terrestrial Gastropoda of the World. Last update: July 16th, 2017. Available online at http://www.molluscabase.org (accessed 21 November 2018)

Bouchet P., Rocroi J. P., HAUSDORF B., KAIM A., KANO Y., NÜTZEL A., PARKHAEV P., SCHRÖDL M., STRONG E. E. 2017. Revised classification, nomenclator and typification of gastropod and monoplacophoran families. Malacologia 61: 1-526. https://doi.org/ 10.4002/040.061.0201

GUDE G. K. 1914. The fauna of British India including Ceylon and Burma. Taylor and Francis, London.

HoRA S. L. 1949. Satpura hypothesis of the distribution of Malayan fauna and flora to peninsular India. Proceedings of the National Institute of Sciences of India 15: 309-314.

INKHAVILAY K., SUTCHARIT C., PANHA S. 2017. Taxonomic review of the tree snail genus Amphidromus Albers, 1850 (Pulmonata: Camaenidae) in Laos, with the description of two new species. European Journal of Taxonomy 330: 1-40. https://doi.org/10.5852/ejt.2017.330

KARANTH P. K. 2003. Evolution of disjunct distribution among wet-zone species of the Indian subcontinent: testing various hypotheses using a phylogenetic approach. Current Science 85: 1276-1283.
Klorvuttimontara S., McClean C. J., Hill J. K. 2017. Evaluating the effectiveness of protected areas for conserving tropical forest butterflies of Thailand. Biological Conservation 144: 2534-2540. https://doi. org/10.1016/j.biocon.2011.07.012

LAIDLAW F. F., SOLEM A. 1961. The land snail genus Amphidromus: a synoptic catalogue. Fieldiana: Zoology 41: 507-677.

MANI M. S. 1974. Biogeographical evolution in India. In: MANI M. S. (ed.). Ecology and biogeography of India. Dr. W. Junk B.V. Publisher, the Hague, Netherlands, pp. 698-724. https://doi.org/10.1007/978-94-010-23313_24

MitrA S. C., DEY A., RAMAKRISHNA. 2004. Pictorial handbook - Indian land snails (selected species). Director, Zoological Survey of India, Kolkata.

Olson D. M., Dinerstein E., Wikramanayake E. D., Burgess N. D., Powell G. V., UnderWood E. C., D'Amico J. A., ItOUA I., STRAND H. E., MORRISON J. C., LOUCKS C. J., ALLNUTT T. F., RicKeTTS T. H., KURA Y., LamoreuX J. F., WeTtengel W. W., HedaO P., KASSEM K. R. 2001. Terrestrial ecoregions of the World. A new map of life on Earth: a new global map of terrestrial ecoregions provides an innovative tool for conserving biodiversity. BioScience 51: 933-938. https:// doi.org/10.1641/0006-3568(2001)051 [0933:TEOTWA]2.0.CO;2 
PILsBRy H. A. 1900. Manual of conchology. Second series: Pulmonata, Volume 13. Academy of Natural Sciences, Philadelphia.

RAMAKRISHNA, Mitra S. C., DEY A. 2010. Annotated checklist of Indian land molluscs. Records of the Zoological Survey of India, Occasional Paper No. 306: $1-359$.

RoONWAL M. L., NATH B. 1949. Discontinious distribution of certain Indo-Malayan mammals, and its zoogeographical significance. Proceedings of the National Institute of Sciences of India 15: 375-377.

SETHY P. G. S., SAHU P., SidDiQUI S. Z. 2007. Malacofauna diversity in Similipal Biosphere Reserve, Mayurbhanj, North Orissa, India. Geobios 34: 109-112.

SOLEM A. 1983. First record of Amphidromus from Australia with anatomical note on several species (Mollusca: Pulmonata: Camaenidae). Records of the Australian
Museum 35: 153-166. https://doi.org/10.3853 /j.0067-1975.35.1983.315

SUTCHARIT C., ABLETT J., TONGKERD P., NAGgS F., PANHA S. 2015. Illustrated type catalogue of Amphidromus Albers, 1850 in the Natural History Museum, London, and descriptions of two new species. ZooKeys 492: 49-105. https://doi.org/10.3897/zookeys.492.8641

SUTCHARIT C., PANHA S. 2006. Taxonomic review of the tree snail Amphidromus Albers, 1850 (Pulmonata: Camaenidae) in Thailand and adjacent areas: subgenus Amphidromus. Journal of Molluscan Studies 72: 1-30. https://doi.org/10.1093/mollus/eyi044

Received: October 20th, 2018

Revised: November 5th, 2018

Accepted: November 6th, 2018 Published on-line: December 11th, 2018 